\title{
SIGNIFIKANSI LEMBAGA AL-HISBAH DALAM SISTEM EKONOMI ISLAM
}

\author{
Khairuddin Wahid \\ Fakultas Syariah IAIN Bengkulu \\ Jl. Raden Fatah Pagar Dewa Bengkulu \\ Email: wahidinstitute.12@gmail.com
}

\begin{abstract}
If the teachings of neoclassical economic systems minimize the role of the state in the market, and conversely the teaching of socialist economic systems maximizes the role of the State in the market, Islamic economic systems teach that markets, countries and individuals are in balance (iqtishâd/equilibrium). This means that for Islamic economic systems, the State is in a unified system. However, Islamic economic systems guarantee a free market mechanism, where sellers and buyers are free to compete fairly in terms of equity. To guarantee the sustainability of this market fairly, from the outset the Messenger of Allah saw attention to the market by conducting an investigation into the market. This sunna is preserved by friends and the Islamic world, which in turn is transformed into an institution of ratio. After observing the objectives, principles, and characteristics of Islamic economic systems, it turns out that the existence of this market watchdog is a necessity, as a logical consequence of the Islamic economic system it self.
\end{abstract}

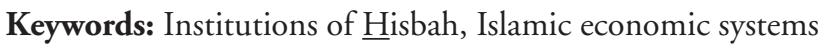

\begin{abstract}
Abstrak: Jika ajaran sistem ekonomi neoklasik meminimalisir peran negara dalam pasar, dan sebaliknya ajaran sistem ekonomi sosialis memaksimalisir peran Negara dalam pasar, maka sistem ekonomi Islam mengajarkan bahwa pasar, Negara dan individu berada dalam keseimbangan (iqtishâd/equilibrium). Artinya bagi sistem ekonomi Islam, Negara berada dalam satu kesatuan sistem. Namun, sistem ekonomi Islam menjamin mekanisme pasar bebas, dimana para penjual dan pembeli bebas bersaing secara wajar dalam kerangka keadailan. Untuk menjamin keberlangsungan pasar secara adil inilah, maka sejak dini Rasulullah saw memeri perhatian terhadap pasar dengan melakukan investigasi ke pasar. Sunah fi'liyah ini dilestarikan oleh para sahabat dan dunia Islam, yang pada gilirannya menjelma sebagai lembaga Hisbah. Setelah dilakukan pencermatan terhadap tujuan, prinsip, dan karekteristik sistem ekonomi islam, ternyata keberadaan lembaga pengawas pasar ini merupakan suatu keniscayaan, sebagai konsekuensi logis sistem ekonomi Islam itu sendiri.
\end{abstract}

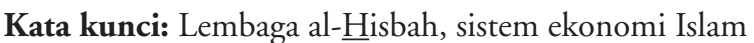

\section{Pendahuluan}

Artikel yang bertajuk "Reposisi Negara Dalam Pasar: Analisis Kritis Terhadap Asumsi Intervensi Pasar Oleh Pemerintah Perspektif Ekonomi Islam" karya Khairuddin Wahid di dalam Jurnal Al-Intaj, ${ }^{1}$ menguatkan asumsi posisi pemerintah dalam pasar dari sudut pandang sistem ekonomi Islam, dimana pasar, Negara dan individu pelaku pasar berada dalam

${ }^{1}$ Khairuddin Wahid, "Reposisi Negara Dalam Pasar: Analisis Kritis Terhadap Asumsi Intervensi Pasar Oleh Pemerintah Perspektif Ekonomi Islam" Al-Intaj; Jurnal Ekonomi dan Perbankan Syariah, Vol. 3, No. 1, Maret 2017, h. 1-25 keseimbangan (iqtishâd/equilibrium). Artinya di dalam sestem ekonomi Islam Negara/pemerintah selalu berada di pasar, dan oleh karenanya jika keadaan pasar menghendaki tindakan "extra" oleh Negara, misalkan mengambalikan stabilitas pasar, dan/atau bila diperlukan menetapkan harga, maka tidak dapat dikatakan sebagai intervensi. Namun demikian, meskipun Negara berada dalam satu kesatuan system pasar, para analis ekonomi Islam tetap berkeyakinan bahawa pasar dijamin kebebasannya oleh Negara, pasar bebas menentukan cara-cara produksi dan harga, tidak boleh ada gangguan yang dapat 
merusak keseimbangan pasar, termasuk oleh Negara sendiri. Dalam posisi yang demikian, maka menurut penulis tidak tepat jika menggunakan istilah intervensi pasar. Istilah yang relatifrepresentatif adalah "pengendalian pasar".

Pada bagian akhir tulisan terebut penulis menawarkan model pengendalian pasar yang komprehensif dan berkesinambungan yang bersifat preventif, kuratif dan represif. Untuk mengimplentasikan medel pengendalian pasar ini, maka sistem ekonomi Islam sejak dini memandang penting lembaga pengawasan yang disebut dengan istilah al- $\underline{H}$ isbah. Tulisan ini mencoba menyajikan analisis diskriptif tentang signifikani lembaga al- $\underline{H}$ isbah bagi pasar dalam sistem ekonomi Islam.

\section{Sistem Ekonomi Islam}

Secara etimologis, istilah ekonomi Islam sepadan dengan istilah bahasa arab al-iqtishâd al-Islâmi. Kata al-iqtishâd sendiri berasal dari qashdun yang berarti keseimbangan (equilibrium) dan keadilan (equally balance). Bisa juga dimaknai dengan penghematan (tidak berlebihan) dan kesederhanaan. $^{2}$

Menurut para pemikir ekonomi Islam, antara lain Muhammad Abdul Mannan bahwa “... a social science which studies the economics problems of the people imbued with the values of Islam". ${ }^{3}$ Maksudnya, ekonomi Islam adalah sebuah cabang ilmu pengetahuan sosial yang membahas masalah-masalah ekonomi masyarakat yang digali dari nilai-nilai Islam.

${ }^{2}$ A.W. Munawir, Kamus al-Munawwir, (Yogyakarta, ttp.), h. 1209. Kata qashdu dengan berbagai derevasinya di dalam Al-Quran diulang beberapa kali, antara lain; (a) qashdu yang bermakna "sederhana" tedapat dalam surat Luqman ayat 19, (b) qashdu yang bermakna "pertengahan" terdapat dalam surat al-Maidah ayat 66, (c) qashdu berarti "jalan yang lurus" tertera dalam surat an-Nahl ayat 9, (d) qashdu dalam arti "dekat" termuat dalam surat at-Taubah ayat 42. Lihat, Muhammad Baltaji, Al-Milkiyah al-Fardiyah fî an-Nazhâm al-Iqtishadî alIslâmî, (Kairo, Dâr as-Salâm, 2007), h. 9-10

${ }^{3}$ Muhammad Abul Mannan, Islamic Economics: Theori and Practice (A Comperative Study), (Delhi: Idarah Adabiyah, 1970), h. 3

\section{Sedangkan menurut Hasanuz Zaman:}

Islamic Economic is the knowledge and applications and rules of the shariah that prevent injustice in the requisition and disposal of material resources in order to provide satisfaction to human being and enable them to perform their obligations to Allah and the society. ${ }^{4}$

Ekonomi Islam adalah pengetahuan dan aplikasinya, yang berasal dari ajaran dan aturan syari'ah yang mencegah ketidakadilan dalam memperoleh manfaat dari sumber daya material untuk dapat memberikan kepuasan kepada manusia dan dapat membantu mereka untuk melaksanakan kewajibannya kepada Allah Swt dan masyarakat. Khan, mengembangkan definisi yang berorientasi kepada tujuan spiritual. "Islamic Economics aims at the study of human falah achieved by organising the resources of earth on the basis of cooperation and participation". Maksudnya, ekonomi Islam bertujuan untuk melaksanakan kajian tentang kebahagiaan hidup manusia, yang dicapai dengan mengorganisir sumber daya alam atas dasar kerja sama dan partisipasi.

Jadi, secara epistemologis ekonomi Islam dipercaya sebagai bagian integral dari ajaran Islam itu sendiri, sehingga pemikiran ekonomi Islam langsung bersumber dari Tuhan. Dengan demikian dalam memenuhi kebutuhan dan keinginannya pada aktifitas ekonomi pasar harus mengacu pada nilai-nilai ajaran Tuhan (baca: Islam) yang pada prinsipnya adalah untuk kemaslahatan manusia itu sendiri, individu maupun secara umum. Berbeda dengan sistem ekonomi konvensional, yang dalam sejarahnya murni dihasilkan oleh pemikiran manusia-teori kapitalis misalkan, yang sangat individualisme dan materialisme-maka yang menjadi pedoman ajaran ekonominya adalah bebas berbuat dan bebas bertindak. ${ }^{6}$

\footnotetext{
${ }^{4}$ Hasanuz Zaman, dalam Toseef Azid, "Anthology of Islamic Economics: Review of Some Basic Issues", Journal Review of Islamic Economics, Vol. 13, No. 2, 2010, h. 165-194.

${ }^{5}$ Khan, M. Akram. "Islamic Economics: Nature and Need", Journal of Research in Islamic Economics, Vol.1(2), 1984, h.51-58.

${ }^{6}$ Andullah Zaky Al Kaaf, Ekonomi dalam Perspektif Islam, (Bandung: Penerbit Pustaka Setia Bandung, 2002), Cet. I, h. 40.
} 


\section{Tujuan}

Secara umum, sesungguhnya tujuan ekonomi Islam tidak lain adalah untuk mewujudkan kemaslahatan bagi umat manusia. Karena itu, maka prinsip-prinsip yang mengarahkan pengorganisasian kegiatan-kegiatan ekonomi, baik itu individu, kelompok, sampai pada negara haruslah dalam rangka pencapaian tujuan kemaslahatan, yaitu: Pertama, jaminan terpenuhinya kebutuhan pokok. ${ }^{7}$ Kedua, jaminan keadilan dalam peran serta ekonomi. ${ }^{8}$ Ketiga, terjaminnya stabilitas dan pertmbuhan ekonomi. ${ }^{9}$

Dengan demikian menurut Agus Trianta, ${ }^{10}$ sebenarnya tujuan ekonomi Islam itu adalah jaminan sosial. Artinya pemenuhan kebutuhan pokok tersebut adalah merupakan tanggung jawab kolektif secara proporsional, ada tanggung jawab invidu, ada tanggung jawab kelompok dan ada juga yang menjadi tanggung jawab negara (pemerintah). Tujuan ekonomi konvensional adalah kesejahteraan invidu. Kemajuan ekonomi (termasuk di Indonesia) selalu diukur dengan income per kapita. Teori kapitalis mengajarkan bahwa kesuksesan ekonomi ditentukan oleh individu masing-masingatau disebut anthropocentrism individualism. ${ }^{11}$

\section{Prinsip Dasar}

a. Prinsip Tauhid.

Satu-satunya prinsip dasar ekonomi Islam adalah tauhid. Dari prinsip tauhid ini serta

${ }^{7}$ Ketidakmampuan memenuhi kebutuhan pokok ini sudah menjadi standar indikator kemiskinan global. Dengan kata lain kemiskinan adalah orang-orang yang tidak mampu memenuhi kebutuhan pokoknya. Lihat M. Ismail Yusanto dan M. Arif Yunus, Pengantar Ekonomi Islam, (Bogor: Al-Azhar Press, 2011), cet.2, h. 69 .

${ }^{8}$ Yang dimaksud dengan keadilan dalam peran serta ekonomi di sini adalah peran masing-masing individu, orang lain dan negara haruslah proporsional. Pemenuhan kebutuhan pokok adalah hak sekaligus kewajiban bagi setiap invidu, orang lain dan negara. M. Ismail Yusanto dan M. Arif Yunus, Pengantar Ekonomi..., h. 82.

${ }^{9}$ M. Ismail Yusanto dan M. Arif Yunus, Pengantar Ekonomi..., h. 88 .

${ }^{10}$ Agus Trianta, Hukum Ekonomi Islam: Dari Politik Hukum Ekonomi Islam Sampai Pranata Ekonomi Syariah, (Yogyakarta: Fakultas Hukum UII Press, 2012), h. 22.

${ }^{11}$ Anwar Abbas, Philopsopy Sistem Ekonomi Islam, (Jakarta: 14 Maret 2012), h. 3. merta memunculkan prisip-prinsip yang lain, ${ }^{12}$ di antaranya: Akhlâq al-Karîmah, keseimbangan, kebebasan individu dan keadilan. Mengacu kepada nilai-nilai filosofis tauhid ini, maka manusia sebagai pelaku ekonomi meyakini bahwa alam dan seisinya ini adalah ciptaan Allah, ${ }^{13}$ milik Allah, yang Maha Esa dan Maha Kuasa, ${ }^{14}$ dan semuanya akan kembali kepada-Nya. Keyakinan bahwa Allah lah satu-satunya yang menciptakan dan yang memiliki alam semesta membawa kesadaran kepada manusia bahwa meskipun ia sebagai khalifah Allah, tapi mempunyai keterbatasan kepemilikan, baik dari segi kapasitas, kekuasaan atau kewenangan, maupun waktu kepemilikan. Keyakinan ini akan melahirkan sikap kebersamaan, toleran dan menghin dari

${ }^{12}$ Rozalinda menawarkan ada lima prinsip dasar ekonomi Islam, Rozalinda, Ekonomi Islam:Teori dan Aplikasinya Pada Aktivitas Ekonomi, ed. 1, cet. 2, (Jakarta: Rajawali Pers, 2015), h. 16-23., Abd. Shomat memerinci delapan prinsip dasar ekonomi Islam, Abd. Shomat juga merilis pendapatnya Sjaikhul Hadi Poernomo yang menawarkan enam prinsip ekonomi Islam, lihat Mardani, Hukum Sistem Ekonomi Islam, (Jakarta: Rajawali Pers, 2015), h. 16-19., M. Umar Chapra sebagaimana dikutip oleh Neni Sri Imaniyati mengemukakan ada lima prinsip ekonomi Islam. Neni juga mengutip Muslimin H. Karra yang membagi prisip ekonomi Islam ke dalam 11 prinsip. Lihat Neni Sri Imaniyati, Perbankan Dsyariah dalam Perspektif Ilmu Ekonomi, (Bandung: Bandar Maju, 2013), h. 29-30.

${ }^{13}$ Menyadari alam semesta dan seisinya adalah ciptaan Allah dan dengan rahmat dan kasih sayang-Nya, Allah mengamanatkan tugas mulia sebagai khalifah kepada seluruh manusia (tanpa kecuali), maka sudah seharusnya manusia menjalin hubungan persaudaraan sesama, bekerja sama dan saling membantu dalam semua aktivitas kehidupan, termasuk di dalamnya adalah aktivitas ekonomi dalam memenuhi kebutuhannya. Lihat Monzer Kahf, The Islamic Economic Analitical of the Functioning of the Islamic Economic System, terj. Makhnum Husen, Ekonomi Islam: Tela'ah Analitik Terhadap Fungsi Sistem Ekonomi Islam, (Yogyakarta: Pustaka Pelajar, 1995), h. 46., Ali Abdurrahman ar-Rasul, Almadâdi' al-Iqtishad fí al-Islâm, (Kairo: Dâr al-Fikr al-'Arabi, 1980), h. 161.

${ }^{14}$ Pengakuan bahwa alam semesta ini adalah ciptaan Allah berati pengakuan bahwa alam semesta adalah milik-Nya, manusia tidak mempunyai apa-apa, semuanya milik Allah, tugas manusia hanyalah mengurus dan memanfaatkan potensi sumber daya untuk memenuhi kebutuhan hidupnya di dunia dan akherat kelak. Dengan demikian, maka sesungguhnya hak manusia atas harta yang dimilikinya hanyalah terbatas hak mengurus dan memanfaatkannya sesuai dengan ketentuanketentuan yang diturunkan-Nya. Faham "kepemilikan mutlak" ditolak oleh Islam. Abu al-A'la al-Maududi, Asas al-Iqtishad al-Islâmî wa an-Nizhâm al-Ma'âsir Mu'dilat al-Iqtishad wa Halluha fí al-Islâm, (Jeddah: Dâr as-Su’udiyah lî an-Nasr wa Tauzi, 1985), h. 13. 
sikap serakah dalam memiliki, mengelola dan memanfaatkan harta. Kesadaran bahwa segala milik Allah pasti akan kembali kepadaNya, akan membawa suasana kebatinan manusia dalam setiap aktivitas ekonominya menuju ridha Allah.

\section{b. Prinsip Akhlâq al-Karîmah}

Untuk memudahkan manusia menjalankan tugas pokok dan fungsinya sebagai khalifah yang memiliki keterbatasan tersebut, maka dengan sifat-Nya yang Maha Bijaksana, Allah menunjuk nabi dan rasul-Nya, membawa petunjuk bagi manusia melalui perkataan, prilaku, sikap dan sifat-sifatnya. Pengalaman sikap dan sifat Rasulullah inilah yang menjadi pedoman dan diikuti dalam setiap aktivitas ekonomi, yaitu: shiddîq, tablìg, amanah, dan fathanah.

c. Prinsip Keseimbangan

Prinsip Tauhid juga akan melahirkan prinsip keseimbangan. Keyakinan bawa Allah satusatunya pencipta dan pemilik mutlak alam semesta dan sumuanya akan kembali kepadaNya, akan melahirkan keseimbangan dalam meraih kebahagiaan dunia dan akherat, keseimbangan meraih hak dan menjalankan kewajiban, keseimbangan kepentingan individu dan kelompok, keseimbangan antara boros dan kikir (Q.S. al-Baqarah [2]: 201, Q. S. al-Qashash [28]: 77), dan seterusnya. Bagi sistem ekonomi konvensional yang cenderung materialisme, segala kegiatan manusia dilatarbelakangi dan diorientasikan kepada segala sesuatu yang bersifat materi. Kebahagiaan manusia adalah jika segala kebutuhan materialnya terpenuhi secara melimpah. Pengertian kesejahteraan yang materialistik seperti ini akan menjauh dari unsur-unsur spritual.Dalam sistem ekonomi kapitalis, materi adalah segala-galanya bahkan dianggap sebagai penggerak utama perekonomian. ${ }^{15}$

${ }^{15}$ Roger LeRoy Miller, Economics Toda: The Micro View, edisi 9, (New York:Addison Wesley, 1997), h. 6. d. Kebebasan Individu

Prinsip kebebasan individu ini sejalan dangan adanya tanggung jawab individu yang harus dimiliki setiap insan dalam menjalankan kehidupaannya, ${ }^{16}$ termasuk di dalamnya aktivitas ekonomi. Dalam menjalankan aktivitas ekonominya, individu muslim harus merdeka, tanpa ada tekanan atau intervensi dari pihak lain. Bebas bukan berati tanpa batas. Sebagai pancaran dari nilai-nilai ketauhidannya, kebebasan individu muslim tentu dibatasi oleh rambu-rambu yang ditetapkan Allah. Sedangkan pada sistem ekonomi konvensional kebebasan individu tanpa batas.

e. Prinsip Keadilan

Keyakinan bahwa semua potensi ekonomi yang ada adalah ciptaan Allah, milik Allah, dan manusia diberikan kewenangan oleh Allah untuk mengurus dan memanfaatkannya. Kewenangan yang diberikan Allah ini tidak boleh disalahgunakan karena setiap aktifitas muslim akan diminta pertangungjawaban oleh Allah. Salah satu aspek terpenting dalam aktivitas ekonomi adalah bertindak adil, karena di samping untuk pertanggungjawaban ke pada Sang Pemilik, juga sebagai dasar untuk mencapai tujuan ekonomi Islam yakni kemaslahatan bersama. Sebaliknya segala bentuk ketidakadilan pasti akan mendatangkan kemufasadatan. Lain halnhya dengan sistem ekonomi konvensional sistem ekonominya sebenarnya tidak diciptakan untuk mencapai tujuan-tujuan keadilan sosio ekonomi yang berdasarkan nilai transendental (spritual) dan persaudaraan universal. Sehingga, fakta ekonomi pada sektor perbankan misalkan praktis dikuasai oleh pegusaha-pengusaha besar. Lembaga perbankan konvensional tidak dinikmati oleh rakyat kecil yang menjadi mayoritas penduduk sebuah negara, termasuk di Indonesia. ${ }^{17}$

${ }^{16}$ Afzalurrahman, Economic Doctrines of Islam, terj. Soerjono dan Nastangin, Doktrin Ekonomi Islam, I (Yogyakarta: Darma Bakti Wakaf, 1995), h. 2-3.

$17 \mathrm{http} / / / \mathrm{www}$.agustiantocentre.com/?p=759, diakses pada tanggal 1 Maret 2018. 


\section{Karakteristik Ekonomi Islam}

a. Menjunjung tinggi nilai-nilai ketuhanan. ${ }^{18}$ Sebagaimana prinsip dasar ekonomi Islam yang diuraikan di atas, setiap manusia harus menyadari bahwa alam dan seisinya, termasuk manusia dan segala potensi sumber daya ekonomi untuk memenuhi kebutuhannya adalah berasal dari Tuhan dan pasti akan kembali kepada-Nya. Oleh sebab itu, segala aktifitas ekonomi jika dilakukan karena Allah dan untuk mengharap ridla-Nya, maka akan bernilai ibadah dan akan mendapatkan pahala.

b. Menjunjung tinggi budi pekerti (akhlâq alkarimah).${ }^{19}$ Karakteristik kedua ini erat sekali hubungannya dengan karakteristik pertama, di mana perilaku terpuji yang disukai Allah dan Rarul-Nya terpatri dalam jiwa raga manusia, sehingga segala aktivitas ekonomi, mulai dari produksi, distribusi sampai sirkulasi tidak pernah lepas dari pancaran sinar akhlâq al-Karîmah. Karakteristik ini menjadikan ekonomi Islam emiliki sistem pengawasan melekat (internal) pada setiap individu pelaku ekonomi.

c. Manusiawi (Insaniyah). Sebagaimana telah dikemukakan bahwa tujuan ekonomi Islam adalah untuk mewujudkan kemaslahatan hidup manusia. Untuk mencapainya, manusia diberi kesempatan yang seluas-luasnya untuk memenuhi kebutuhan hidupnya, memenuhi kewajiban kepada Tuhan, kepada diri dan keluarga, orang lain, bahkan kepada negara. ${ }^{20}$

d. Keseimbangan (tawazun).

Kemaslahatan hidup yang ingin dicapai dalam ekonomi Islam tidak hanya kehidupan duniawi semata, melainkan juga kehidupan ukhrawi (Q.S. al-Baqarah [2]: 201 dan Q. S. al-Qashash [28]: 77). Yusuf al-Qardhawi menjelaskan, ${ }^{21}$ bahwa usaha pemenuhan

${ }^{18}$ Yusuf al-Qardhawi, Daur al-Qiyâm wa al-Akhlâq di alIqtishâd al-Islâmî, (Kairo: Maktabah Wahbah, 1995), h. 27-29.

${ }^{19}$ Yusuf al-Qardhawi, Daur al-Qiyâm..., h. 29.

${ }^{20}$ Yusuf al-Qardhawi, Daur al-Qiyâm..., h. 29.

${ }^{21}$ Yusuf al-Qardhawi, Khashaish al-Ammah lî al-Islàm, kebutuhan hidup duniawi haruslah berbanding lurus dengan usaha pemenuhan kebutuhan ukhrawi. Sebaliknya, Teori ilmu ekonomi konvensional menganggap manusia senantiasa ingin mencapai keuntungan material sebanyak-banyaknya, tanpa batas. Mereka seolah mengingkari fakta bahwa sebenarnya ada batasan-batasan tertentu dalam memenuhi keinginannya. ${ }^{22}$

\section{Mekanisme Pasar Islami}

Kajian tentang ekonomi Islam secara umum,-termasuk di dalamnya mengenai srtuktur pasar dan mekanisme terbentuknya harga — sudah mendapatkan perhatian dari para ulama klasik jauh sebelum para ilmuan modern membangun dan mengembangkan teori-teori ekonominya, antara lain Abu Yusud (737-798), Abu Hamid al-Ghazali (1058-111), Ibn Taimiyah (1283-1328), dan Ibn Khaldun (1332-1404). Bahkan disinyalir menjadi sumber inspirasi para ilmuan modern membangun teori-teori ekonominya. ${ }^{23}$

Ekonomi Islam memandang, keberadaan pasar adalah sebuah keniscayaan. Al-Gazali, ${ }^{24}$ yang terkenal dengan teori evolusi pasarnyamembuat ilustrasi bahwa sudah menjadi fitrah manusia selalu membutuhkan orang lain. Adalah sulit jika untuk memenuhi kebutuhannya itu masing-masing mencari orang lain yang memiliki barang yang dibutuhkannya untuk ditukarkan dengan barang yang dimiliknya. Oleh sebab itu, manusia memerlukan tempat penyimpanan dan pendistribusian. Tempat inilah yang kemudian didatangi banyak orang untuk mendapatkan barang yang dibutuhkannya. Inilah cikal bakal

(Kairo: Maktabah Wahah, 1989), h. 115.

22 Syed Omar Syed Agil, "Rationality in Economic Theory: A Critical Appraisal”, dalam Sayyid Tahir et al. (ed.), Readings in Microeconomics An Islamic Perspective, (Petaling Jaya: Longman Malaysia Sdn Bhd, 1992), h. 36.

${ }^{23}$ Muhammad Anis Matta, "Sejarah Pemikiran Ekonomi Islam”, dalam Mustafa Kamal (ed.), Wawasan Islami dan Ekonomi: Sebuah Bunga Rampai (Jakarta, LP-FEUI, 1997, 9192., Rozalinda, Ekonomi Islam..., h. 148-149.

${ }^{24}$ Al-Gazali, Ihyâ U'lûddîn, jilid III, (Beirut, Dâr anNadwah, t.th), h. 227. 
terbetuknya pasar, yang mekanismenya masih sangat sederhana.

Sejalan dengan perkembangan peradaban manusia, kemudian pasar berkembang dengan berbagai bentuk dan mekanismenya, sampai pada yang paling medern di era digital saat ini. Bagi ekonomi Islam tidak ada pembatasan atau pembagian struktur tertentu, apakah itu persaingan sempurna, monopoli, oligopoli, monopsoni atau oligopsoni sebagaimana teori yang dikembangkan oleh para pakar ekonomi konvensional di atas. Pasar terbangun dengan sendirinya atas dasar kebebasan individu untuk melakukan transaksi barang dan jasa. Kebebasan individu yang dimaksud adalah bukan kebebasan tanpa batas. Rambu-rambu kebebasan dalam bertransaksi sangat jelas dan tegas, secara umum yaitu sepanjang tidak mengganggu atau merusak tujuan kemaslahatan umum. Jujur dan adil adalah salah satu contoh rambu-rambu yang tegas yang tidak boleh dilanggar demi tercipnya kemaslahatan bersama.Namun demikian selalu saja ada gangguan (pelanggaran rambu-rambu) dalam kesempurnaan pasar, yang disebut dengan distorsi pasar.

Maksud distorsi pasar di sini adalah hal-hal yang dapat mengganggu bekerjanya mekanisme pasar secara alami. Gangguan-gangguan tersebut dapat berasal dari beberapa sebab, di antaranya adalah dari unsur permintaan maupun penawaran yang terjadi di pasar, struktur pasar, masalah eksternalitas dan masalah barang publik. ${ }^{25}$ Masalah eksternalitas ini bisa positif, bisa juga negatif. Eksternalitas positif adalah dampak yang memberikan hasil positif terhadap masyarakat, seperti pembangunan jalan menjadikan suatu daerah terbuka aktivitas dan kegiatan perekonomian dan berakibat pada semakin majunya perekonomian yang terdapat di suatu daerah. Sedangkan eksternalitas negatif adalah dampak yang berakibat negatif pada

${ }^{25}$ Jusmaliani, Kebijakan Ekonomi dalam Islam, (Yogyakarta: Kreasi Wacana, 2005), 221., Eksternalitas berasal dari tindakan memproduksi atau mengkonsumsi suatu produk yang mempunyai pengaruh pada pihak lain, sedangkan pihak yang merasakan dampaknya tidak memperoleh suatu kompensasi dari yang menimbulkan dampak tersebut., Kusnadi, Kusdi Rahardjo dan Rudi Zaedan, Ekonomi Mikro Dilengkapi Pendekatan Akuntansi, (Malang: Universitas Brawijaya, 1997), h. 488. masyarakat, seperti polusi udara yang ditimbulkan akibat pembangunan suatu jalan tol menyebabkan terjangkitnya ISPA (Infeksi Saluran Pernafasan Akut) di masyarakat. ${ }^{26}$ Sementara yang dimaksud dengan barang publik adalah suatu barang atau jasa yang dapat dikonsumsi oleh seseorang atau individu tetapi tidak ada halangan bagi orang lain untuk ikut mengkonsumsinya. ${ }^{27}$ Barang publik mempunyai manfaat bagi masyarakat luas namun tak satupun perusahaan yang dapat mempengaruhinya. Konsumsi individu barang publik tidak akan menyebabkan persaingan terhadap konsumen lainnya. Setiap individu dapat mengkonsumsi suatu produk tanpa mengurangi kenikmatan konsumen lainnya. ${ }^{28}$

Adiwarman mensinyalir ada tiga bentuk distorsi pasar dalam ekonomi Islam: rekayasa penawaran dan permintaan, tadlis (penipuan), dan taghrir (kerancuan). ${ }^{29}$

\section{Rekayasa permintaan dan penawaran.}

a. Bai al-najasy, yaitu penjual berpura-pura tidak ingin menjual barangnya dengan tujuan agar pembeli menawar dengan harga yang mahal. ${ }^{30}$ Bai an-najasy dilarang oleh

${ }^{26}$ M. Nur Rianto Al Arif dan Euis Amalia, Teori Mikro Ekonomi: Suatu Perbandingan Ekonomi Islam Dan Ekonomi Konvensional, (Jakarta: Kencana, 2010), h. 26.

${ }^{27}$ Bradley R. Schiller, TheMicro Economy Today, (New York: McGraw-Hill, 2003), h. 41.

${ }^{28}$ Contoh dari barang publik ini adalah jalan raya. Maka jika seseorang menggunakan jalan raya, orang lain juga dapat menggunakannya tanpa mengusik kepuasan pengguna yang pertama. Pada umumnya, barang publik dihasilkan oleh pemerintah sebab perusahaan tidak mau memproduksinya.Hal ini tentu karena perusahaan swasta selalu berorientasi pada laba sedangkan barang publik tidak dapat dikaitkan dengan laba. Lihat Kusnadi, Kusdi Rahardjo dan Rudi Zaedan, Ekonomi Mikro Dilengkapi Pendekatan Akuntansi, h. 487-488.

${ }^{29}$ Di Dalam literatur fikih, rekayasa penawaran (false supply) lebih dikenal dengan ihtikar, sedangkan rekayasa permintaan (false demand) dikenal sebagai bai' najasy.Sementara tadlis (penipuan/ unknown to one party) dapat mengambil empat bentuk, yaitu penipuan menyangkut jumlah barang (quantity), mutu barang (quality), harga barang (price), dan waktu penyerahan barang (time of delivery). Sama halnya dengan tadlis, taghrir (kerancuan/ ketidakpastian) juga mengambil empat bentuk; yaitu kerancuan menyangkut jumlah barang (quantity), mutu barang (quality), harga barang (price), dan waktu penyerahan barang (time of delivery). Adiwarman A. Karim, Ekonomi Mikro Islam, h. 219.

${ }^{30}$ Ahmad al-Syarbasi, al-Müjâm al-Iqtishâdî al-Islâmî, (t.tp: Dâr al-Jîl, 1981), h. 455. 
Islam, berdasarkan hadis:

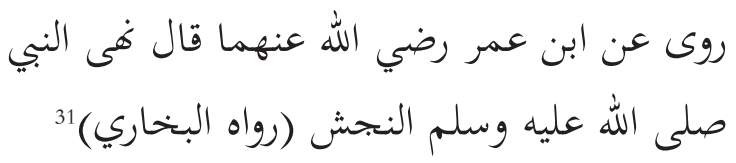

Diriwayatkan dari Ibnu Umar ra., bahwa Rasulullah saw., melarang jual beli najasy" (HR. Bukhari).

b. I $\underline{h} t i k a \hat{r}$ (penimbunan), adalah perbuatan menahan barang dari peredaran di pasar sehingga harganya menjadi naik ketika barang-barang sudah mulai langka dan masyarakat dalam keadaan sangat membutuhkannya. $^{32}$

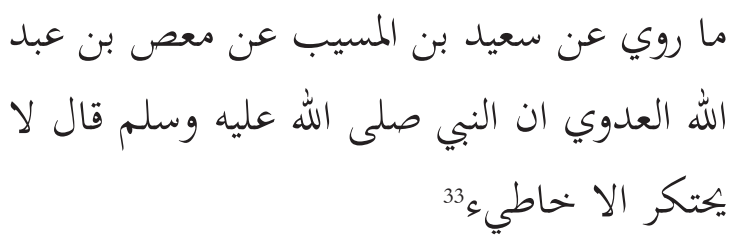

Diriwayatkan dari Said bin Musayyab, dari Mu'ash bin 'Abdillah al-Adawi, sesungguhnya Nabi Muhammad saw. bersabda: tidaklah orang yang melakukan ihtikar itu, kecuali ia berdosa.

c. Talaqqî Rukbân, adalah tindakan pelaku pasar (pedagang) yang sengaja menyetop atau menghentikan perjalanan barang dari luar kota menuju kota (pasar), dan memborong semua barang dagangan sebelum sampai ke pasar, dengan tujuan untuk mendapatkan harga yang lebih murah dibandingkan dengan harga pasar, karena pelaku memiliki informasi tentang harga di pasar.

Praktik seperti ini dilarang dalam Islam, sebagaimana termaktub dalam Hadits berikut:

حدثنا عبدالله ابن يوسف اخبرنا مالك عن النافع عن عبدالله ابن عمر رضيالله عنهما ان رسول الله صلى

${ }^{31}$ Abû 'Abdillâh Muhammad ibn Ismâ'îl ibn Ibrâhim ibn al-Mugîrah al-Bukhârî, Shahîh al-Bukhârî, juz 7 (t.tp: Mawqi' al-Islâm, t.th.), h. 348 .

${ }^{32}$ Yusuf al-Qardlawi, Dawr al-Qiyâm wa al-Akblâq fi alIqtishâd al-Islâmî, (Kairo: Maktabah Wahbah, 2001), h. 293.

${ }^{33}$ Abûal-Husain Muslim bin al-Hajjâj bin Muslim al-Qushairî al-Naisaburî , al-Jâ mi' al-Shahîh al-Musammâ Shahîh Muslim, juz 5 (Beirut: Dâr al-Jîl wa Dâr al-Afâq al-Jadîdah, t.th.), h. 56.

$$
\text { ولا تلقوا السلع حتى يهبت وسلم قلال لا بيبع بعضكم على بيع بعض الى السوق }
$$

Abdullâh ibn Yûsuf telah menceritakan kepada ku, Mâliktelahmengabarkan kepadaku, dari nâfi' dari 'Abdullahb ibn Umar ra. bahwa sesungguhnya Rasûlullâh saw. telah bersabda, janganlah kalian menjual di atas jual beli sebagian yang lain, dan janganlah kalian mencegat barang-barang dagangan, hingga ia sampai ke pasar.

\section{Tadlîs}

Agar terwujud prinsip 'an tarâdhin (suka sama suka) dalam bisnis, maka para pihak seharusnya bertindak transparan, tidak boleh ada yang disembunyikan, baik itu tentang spesifikasi barang, menyangkut harga maupun waktu penyerahan barang. Jika ada yang disembunyikan, maka inilah yang disebut dengan tadlîs atau penipuan (unknown to one party). Allah dan Rasul-Nya melarang segala bentuk penipuan dalam berbisnis, sebagaimana Firman-Nya:

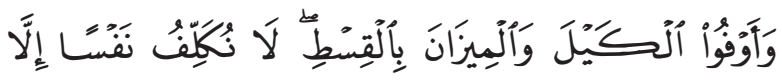

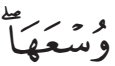

"Dan sempurnakanlah takaran dan timbangan dengan adil. Kami tidak memberi beban kepada seseorang melainkan sekedar kesanggupannya".

Diriwayatkan oleh Imam Muslim, Rasulullah saw bersabda:

عن ابي هريرة ان رسوال الله صلى الله عليه وسلم مر على صبرة طعام فأدخل يده فيها فنالت أصابعه بلا فقال ما هذا يا صحب الطعام؟ قال اصابته السماء يا رسول الله قال أفلا جعلته فوق الطعام كي يراه الناس ؟ من غش

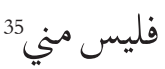

${ }^{34}$ Abû 'Abdillâh Muhmmad ibn Ismâ'îl ibn Ibrâhim ibn alMugîrah al-Bukhârî, Shahîh al-Bukhârî, h. 381. Adiwarman A. Karim, Ekonomi Mikro Islam, h. 225.

35 Muslim ibn al-Hajjâj Abû al-Husain al-Khushairî alNaisâbûri, Shahîh Muslim, jus I, hadis ke-78 (Beirut: Dâr Ihyâ al-Turâts al-'Arabî, t.th.), h. 69. 
"Dari Abi Hurairah bahwa sesungguhnya Rasulullah pernah lewat dan bertemu dengan penjual makanan. Lalu Rasulullah memasukkan tangannya ke dalam makanan itu, dan mendapati jari-jarinya dalam keadaan basah. Rasulullah lalu bertanya, wahai pemilik makanan, apa ini? Dan pemilik makanan itu menjawab,"hujan telah menimpanya wahai Rasulullah". Rasulullah lalu berkata lagi, mengapa engkau tidak meletakkannya di atas saja, supaya orang-orang dapat melihatnya?, siapa yang melakukan penipuan, maka dia tidak termasuk dalam golonganku”. (Q. S. Al-An'âm [6]: 152)

Ada empat macam tadlîs: tadlîs dalam kuantitas, tadlîs dala kualitas, tadlîs dalam harga dan tadlîs dalam waktu penyerahan.

\section{Taghrîr (Kerancuan).}

Taghrîr berasal dari akar kata gharra - gharru - gharran wa ghurratan wa ghurûran yang berarti menipu, memperdayakan. Baiu al-gharar artinya penjualan sesuatu yang tidak terang rupa dan sifatnya. ${ }^{36}$ Di dalam fikih muamalah, istilah taghrîr berarti melakukan sesuatu tanpa didasari oleh pengetahuan yang memadai. ${ }^{37}$ Sebagaimana tadlîs, maka taghrîr juga ada empat macam: Taghrîr dalam kuantitas, taghrîr dalam kualitas, taghrîr dalam harga dan taghrîr dalam waktu penyerahan.

Jelas sekali bahwa di dalam ekonomi Islam empat unsur terpenting dalam bertransaksi yakni kualitas, kuantitas, harga dan waktu penyerahan barang harus jelas, tidak boleh ada yang samar, apalagi tidak diketahui oleh masingmasing pihak.

\section{Pembentukan Harga dalam Islam}

Konsep dasar ekonomi Islam tentang pembentukan harga bersumber dari hadits Rasûlullâh saw.

\footnotetext{
${ }^{36}$ Ahmad Warson Munawwir, Al Munawwir, Kamus ArabIndonesia, (Yogyakarta: Pondok Pesantren Al-Munawwir, t.th.), h. 1074 .

37 Afzalurrahman, Doktrin Ekonomi Islam, (Yogyakarta: Dana Bhakti Wakf, 1996), h. 161.
}

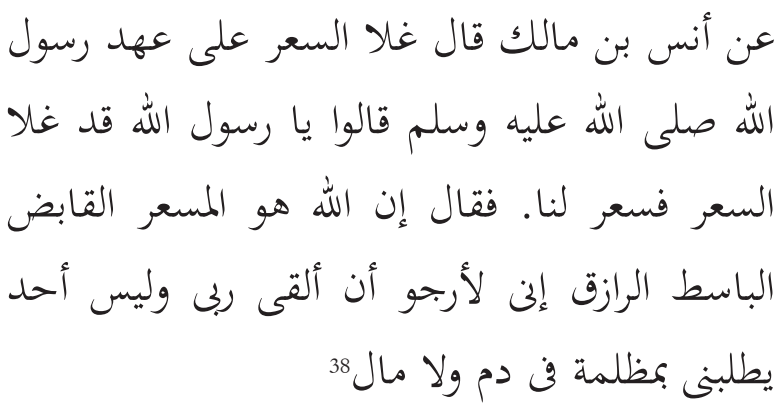

"Pernah naik harga (barang-barang) di Madinah zaman Rasûlullâh saw. Orang-orang berkata "Ya Rasûlallâh, telah naik harga, karena itu tetapkanlah harga bagi kami" Rasûlullâh saw. bersabda, "Sesungguhnya Allâh itu penetap harga, yang menahan, yang melepas, yang memberi rejeki dan sesungguhnya aku harap bertemu Allâh di dalam keadaan tidak seorangpun dari kamu menuntut aku lantaran menzalimi di jiwa atau di harga"

Tampak jelas di dalam hadits tersebut bahwa Rasûlullâh saw tidak berkenan menentukan harga. Rasûlullâh saw mengisyaratkan bahwa ketentuan harga itu sepenuhnya diserahkan kepada mekanisme pasar yang alami. Dari hadits di atas dapat dikatakan bahwa hukum supply and demand merupakan sunnatullah. ${ }^{39}$ Harga ditentukan oleh kekuatan pasar itu sendiri, yaitu kekuatan permintaan dan kekuatan penawaran, dimana antara permintaan (pembeli) dan penawaran (penjual) terjadi kesepakatan atas dasar kerelaan, sebagaimana firman Allah:

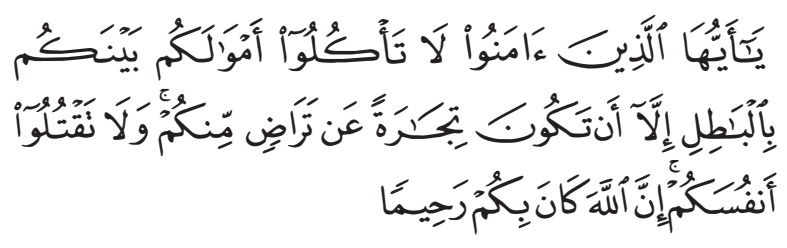

"Wahai orang-orang yang beriman! Janganlah kamu saling memakan harta sesamamu dengan jalan yang batil (tidak benar), kecuali dalam perdagangan yang berlaku atas dasar suka sama

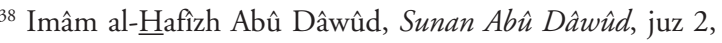
(Beirut: Dâr al-Kutb al-Ilmiyyah, t.th.), h. 479.

${ }^{39}$ Menurut pakar ekonomi Islam kontemporer, teori inilah yang diadopsi oleh Bapak Ekonomi Barat, Adam Smith dengan nama teori invisible hands.Menurut teori ini, pasar akan diatur oleh tangan-tangan tidak kelihatan (invisible hands). Bukankah teori invisible hands itu lebih tepat dikatakan God Hands (tangantangan Allah). Adiwarman A. Karim, Ekonomi Islam:Suatu Kontemporer, (Jakarta: Gema Insani Press, 2003), h. 76.
} 
suka di antara kamu. Dan janganlah kamu membunuh dirimu. Sungguh, Allah Maha Penyayang kepadamu." (Q. S. Al-Nisâ' [4]:29)

Asas tarâdhin (kerelaan) ini dapat difahami bahwa bertransaksi dalam konsep ekonomi Islam, salah satu pihak tidak boleh ada yang merasa dirugikan atau terzalimi, baik di saat transaksi (satu majlis) maupun setelahnya. Demikian pasar ideal (persingan sempurna) yang dikehendaki oleh sistem ekonomi Islam, seperti telah dikemukan di atas.

\section{Pengendalian Harga}

Dalam literatur Ekonomi Islam ditemukan beberapa istilah tentang pengendalian pasar atau pengendalian harga oleh pemerintah, antara lain: Pegendalian, Intervensi (campur tangan), kontrol dan mengatur/pengaturan. Dalam hal ini penulis menghindari istilah intervensi, dengan asumsi bahwa sistem ekonomi Islam memandang pasar, pemerintah dan pelaku pasar adalah satu kesatuan dalam satu sistem pasar. Artinya pemerintah sendiri masuk dalam sistem pasar dengan pengawasannya. jadi tidak tepat kalau memakali istilah intervensi. ${ }^{40}$

Karena ekonomi Islam menganut sistem pasar bebas, harga ditentukan oleh mekanisme pasar, sesuai dengan kekuatan penawaran dan permintaan (supply and demand), maka pada prinsipnya pemerintah tidak boleh mengatur, mengendalikan atau menetapkan harga. Akan tetapi sistem ekonomi Islam juga tidak menutup kemungkinan adanya situasi dan kondisi pasar

40 Dalam literatur Ekonomi Islam ditemukan beberapa istilah tentang pengendalian pasar atau pengendalian harga oleh pemerintah, antara lain: Pegendalian, Intervensi (campur tangan), kontrol dan mengatur/pengaturan. Dalam disertasi ini penulis menghindari istilah intervensi, dengan asumsi bahwa sistem ekonomi Islam memandang pasar, pemerintah dan pelaku pasar adalah satu kesatuan dalam satu sistem pasar. Artinya pemerintah sendiri masuk dalam sistem pasar dengan pengawasannya. jadi tidak tepat kalau memakali istilah intervensi. Lebih lanjut dapat dilihat dalam Khairuddin, makalah berjudul "Reposisi Negara dalam Pasar (Analisis Kritis Terhadap Asumsi Intervensi Pasar Oleh Pemerintah, Perspektif Ekonomi Islam)". Paper ini telah didiskusikan pada sidang ujian komprehensif Program Doktor Pascasarjana UIN Sunan Kalijaga Yogyakarta, pada tanggal 2 November 2016. tertentu yang membolehkan bahkan mungkindalam keadaan darurat-mewajibkan otorita untuk mengontrol harga.

Ibnu Taimiyah mengemukakan ada enam indikator situasi dan kondisi di mana otorita boleh dan atau bahkan wajib megendalikan harga, sebagai berikut:

1) Penjual tidak mau menjual barangnya kecuali pada harga yang lebih tinggi dari pada harga normal, sementara pada waktu yang sama konsumen sangat membutuhkanya. ${ }^{41}$

2) Terjadi diskriminasi harga yang dilakukan oleh pembeli atau penjual karena salah satu dari kedua belah pihak tidak mengetahui harga pasar yang sebenarnya. ${ }^{42}$

3) Terjadi krisis pangan dan kebutuhan pokok lainnya, ${ }^{43}$ misalkan karena terjadi bencana atau peperangan.

4) Para penjual menawarkan harga yang terlalu tinggi, sementara para pembeli menginginkan terlalu rendah. ${ }^{44}$ Jika hal ini dibiarkan akan menimbulkan kemandegan dalam pasar.

5) Terjadi konspirasi antar penjual atau antar pembeli untuk menetapkan harga yang menguntungkan mereka secara sepihak, dan merugikan pihak lain dengan menaikkan harga barang yang mereka jual, atau menurunkan harga barang yang mereka beli. Konspirasi seperti ini menurut Ibnu Taimiyah jauh lebih jahat ketimbang mencegat dagangan sebelum sampai ke pasar (talaqqi rukbân), lebih jahat dari makelar, dan lebih jahat dari bầ' annajasyu. ${ }^{45}$

6) Jika tidak ada titik temu antara pekerja dengan industri pemakai jasa menyangkut besaran upah atau jasa profesi yang dibutuhkan. Misalkan tenaga kerja menolak bekerja kecuali pada upah yang lebih tinggi di atas upah yang berlaku umum (wajar). Pada

\footnotetext{
${ }^{41}$ Ibn Taimiyyah, Public Duties in Islam, h. 36.

${ }^{42}$ Ibn Taimiyyah, Public Duties in Islam, h. 36.

${ }^{43}$ Ibn Taimiyyah, Public Duties in Islam, h. 37.

${ }^{44}$ Ibn Taimiyyah, Public Duties in Islam, h. 37.

${ }^{45}$ Ibn Taimiyyah, Public Duties in Islam, h. 37.
} 
saat yang sama tenaga kerja tesebut sangat dibutuhkan, telebih menyangkut produksi yang barang-barang yang sangat dibutuhkan utuk kepentingan umum. ${ }^{46}$

\section{Regulasi Harga}

Kebolehan otorita mengontrol harga seperti pada poin " $c$ " di atas tidak serta merta pemerintah lantas boleh sewenang-wenang mengatur harga, akan tetapi harus dengan pertimbangan yang matang dan melalui proses yang benar, ${ }^{47}$ jangan sampai turun tangannya pemerintah mengontrol harga justeru berakibat lebih buruk terhadap keberlangsungan pasar dan ekonomi masyarakat. Apalagi peluang pengendalian harga ini disalahgunakan oleh penguasa untuk kepentingan kekuasaannya. Kemungkinan-kemungkinan seperti ini sudah diwanti-wanti oleh Ibnu Taimiyah yang dikenal dengan dua macam penetapan harga oleh pemerintah, yaitu: penetapan harga yang adil dan sah dan penetapan harga yang tidak adil dan melawan hukum. Penetapan harga yang adil dan sah adalah kontrol harga yang dilakukan pemerintah atas dasar fakta situasi dan kondisi riil di pasar yang menngharuskan pemerintah mengontrol harga, jika tidak maka diyakini akan menimbulkan kerugian atau penderitaan bagi masyarakat. Pelaksanaan penetapan harus melalui proses musyawarah yang melibatkan semua pihak terkait dan orang lain yang mengetahui persoalan yang sedang terjadi dan seterusnya. Untuk meminimalisir kemungkinan-kemungkinan buruk akibat kontrol harga oleh otorita ini, maka sistem ekonomi Islam merekomendasikan agar kontrol harga dilakukan dengan terlebih dahulu pemerintah membuat kebijakan berupa regulasi. Mengenai teori kebijakan Islami akan disajikan tersendiri.

\footnotetext{
${ }^{46}$ Ibn Taimiyyah, Public Duties in Islam, h. 43.

47 Ibnu Taimiyah merekomendasikan, sebelum kontrol harga dilakukan, pemerintah harus mengundang pada pelaku pasar dan pihak-pihak terkait lainnya untuk mermusyawarah. Sehingga harga yang ditetapkan oleh pemeritah tersebut pada prisipnya adalah hasil musyawarah (sukarela). Ibnu Taimiyah, Public Duties in Islam, diterjemahkan dari bahasa Arab "AlHisbah fî al-Islâm” oleh Muhtar Holand, (London: The Islamic Poundatian, 1982), h.50.
}

\section{Lembaga al- $\underline{H}$ isbah}

Di dalam sistem ekonomi Islam pengawasan pasar dilakukan oleh sebuah lembaga yang dikenal dengan Wilâyah al- $\underline{H}$ isbah, ${ }^{48}$ yaitu lembaga yang dibentuk oleh pemerintah khusus untuk mengawasi pasar. ${ }^{49}$ Menurut sejarahnya embrio al- $\underline{H}$ isbah ini sudah ada sejak zaman Rasulullah saw. Hal ini dibuktikan dengan beberapa riwayat, bahwa Rasulullah saw pernah menjalankan fungsi al- $\underline{H}$ isbah dengan melakukan pengawasan pasar secara langsung agar tidak terjadi berbagai bentuk kecurangan yang berpotensi merugikan orang lain. Hadits berikut ini menceritakan saat Rasulullah saw melakukan investigasi ke pasar:

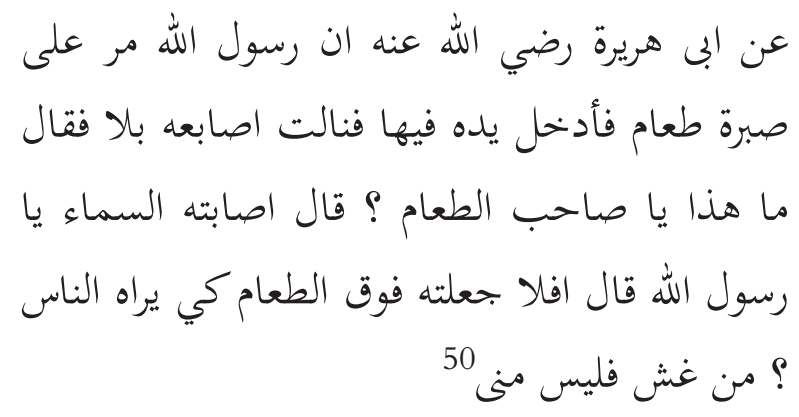

48 Wilâyah artinya kekuasan dan kewenangan, dan alHisbah berarti menghitung, menakar, kalkulasi, berfikir dan lain-lain. Ahmad Warson Munawwir, al-Munawwir Kamus Arab-Indonesia, (Yogyakarta, t.tp, 1984), 282 dan 1684. Bentuk verbal dari hasabah (ihtasaba) berarti mempertimbangkan, mengharapkan pahala di akherat dengan menambahkan amal saleh pada saat perhitungan seseorang dengan Allah. Lihat Cowan, M., A Dictionary of Modern Written Arabic, (Beirut: Librairie du Liban, 1974), h. 186.

49 Secara etimologi al-Hisbah adalah "wewenang memerintahkan untuk menjalakan amar ma'ruf ketika yang ma'ruf tersebut sudah benar-benar ditinggakan, dan mencegah kemungkaran jika jelas-jelas dikerjakan orang", lihat, alMawardi, Al-Ahkâm as-Sulthâniyah wa al-Wilâyât ad-Dîniyah, (Bairut: Dar al-Fikr, 1996), 299. Meskipun secara khusus tidak menjelaskan tetang definsi al-hisbah, Ibnu Taimiyah mengisyaratkan bahwa al-hisbah adalah sebuah lembaga yang mempunyai wewenang untuk menjalankan 'amar ma'rûf dan nahyu an al-munkar, lihat Ibnu Taimiyah, al-Hisbah fi alIslâm, (Riyâdh: al-Muassasah as-Sa'idiyah, t.t), 26. Sedangkan Ibnu Khaldûn mengemukakan, yang intinya al-hisbah adalah lembaga dan petugasnya (muhtasib) dibentuk dan diangkat oleh pemerintah, untuk menjalankan kewajiban keagamaan yang berkaitan dengan menyuruh berbuat baik dan melarang berbuat mungkar, Abd ar-Rahmân ibn Khaldûn, Muqaddimah Ibn Khaldûn, cet. I, (Beirut: Dar al-Kutub al-'Ilmiyah, 1993), 176. Pengertian lebih spesifik dikemukakan oleh A. A. Islahi, yakni sebuah kantor atau lembaga yang berfungsi sebagai pengontrol pasar dan mora secara umum, Abdul Azim Islahi, Economic Concepts of Ibn Taimiyah, (Aligarh: Muslim Universiti Aligarh, 1980), h. 183.

50 Muslim ibn al-Hajjâj Abû al-Husain al-Khushairî an- 
"Dari Abi Hurairah, bahwa sesungguhnya Rasulullah saw. pernah lewat dan bertemu dengan penjual makanan. Lalu Rasulullah memasukkan tangannya ke dalam wadah makanan itu, dan mendapati jari-jarinya dalam keadaan basah. Rasulullah lalu bertanya, wahai pemilik makanan, apa ini? dan pemilik makanan itu menjawab, "bujan telah menimpanya wahai Rasulullah". Rasulullah lalu berkata lagi, mengapa engkau tidak meletakkannya di atas saja, supaya orang-orang dapat melihatnya? siapa yang melakukan penipuan, maka dia tidak termasuk dalam golonganku."

Dari hadits ini terlihat bahwa Rasulullah saw. dalam melakukan pengawasan, memberi penekanan pada fungsi pencegahan di samping penindakan manakala ditemukan pelanggaran di pasar. Fungsi pengawasan, pencegahan dan penindakan ini diteruskan oleh Khulâfá arRâsyidûn. Abû Bakar, ${ }^{51}$ dikabarkan cukup intens dalam mengawasi pasar secara langsung, di samping kesibukannya menghadapi orang-orang murtad dan nabi palsu, juga memerangi orangorang muslim yang enggan membayar zakat. Umar Ibn al-Khaththâb memberikan perhatian khusus terhadap prilaku pelaku pasar. Diriwayatkan, bahwa suatu ketika Umar Ibn al-Khaththâb sedang mengawasi pasar di Madinah, menemukan seorang tukang angkut dengan menggunakan unta, lalu Umar memukul orang tersebut sambil berkata: "bermurah hatilah kepada ontamu, jangan kamu bebani di luar kemampuannya". ${ }^{52}$ Berbeda dengan Abû Bakr dan 'Umar Ibn al-Khaththâb, yang melakukan pengawasan pasar secara langsung, Utsmân Ibn 'Affân mendelegasikan tugasnya

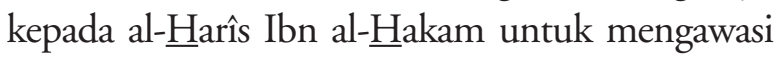
pasar. Eksistensi al- $\underline{H i s b a h ~ p a d a ~ m a s a ~ ' A l i ̂ ~ I b n ~}$

Naishâbûr, Shahîh Muslim, juz 1, Hadis ke-78 (Beirut: Dâr ihyâ at-Turâts al-'Arabî, t.th), h. 69.

51 Jalâluddîn as-Suyûthî, Tarîkh al-Khulafâ' ar-Râsyidîn, (Beirut: Dar al-Fikr, t.t.), h. 76-77.

${ }^{52}$ Alâ' ad-Dîn al-Muttaqî Ibn Hisâm ad-Dîn al-Hindî, Kanz al-Ummal fì Sunan al-Aqwâl wa al-Af'âl, (Beirut: Mu'assah arRisâlah, 1989), 113. Umar disebutkan sebagai orang pertama mengontrol harga dalam Islam, dibuktikan dengan peristiwa ketika Umar menegur Hâthib ibn Balta'ah yang menjual anggur di bawah harga normal, Imâm Mâlik Ibn Anas, Al-Muwaththa' lî al-Imâm Mâlik, kitab al-Buyû' bâb al-Hukrah wa Tarabbush, (Mesir: Dâr Ihyâ' at-Turâts al-'Arabi, t.t.), h. 651.
Abi Thâlib dapat dilihat antara lain pada suatu ketika Alî Ibn 'Abi Thâlib berjalan melewati para pedagang, lantas ia berkata "bertaqwalah kepada Allah, jangan mengumbar sumpah, meskipun dengan sumpah itu dapat memudahkan penjual barang, tetapi akan menghilangkan barakah". ${ }^{3}$ Namun demikian, sampai di sini al- $\underline{\text { Hisbah belum }}$ menjadi sebuah lembaga, sifatnya masih personal, langsung dijabat dan dilaksanakan oleh khalifah, atau menunjuk orang lain yang diberi tugas khusus mengawasi pasar. Al- $\underline{H}$ isbah berkembang menjadi sebuah lembaga/institusi untuk pertama kalinya pada masa Khalifah al-Mahdi al-Abbasiyah (775-785 M), pendapat lain menyebutkan lebih awal, yaitu pada awal pemerintahan Abû Ja'far alMansur (745-775 M)..$^{54}$

\section{Wewenang al-Hisbah}

Lembaga al- $\underline{H}$ isbah dalam Islam pada awalnya mempunyai kewenangan sangat luas, yaitu meliputi seluruh pelanggaran terhadap prinsipprinsip 'amr ma'rûfdan nahyi al-munkâr, baik itu

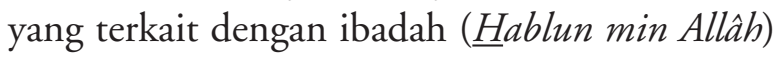
maupun yang berhubungan dengan pelanggaran sosial, ekonomi ( $\underline{H} a b l u n$ min an-nâs), atau yang berhubungan dengan keduanya (

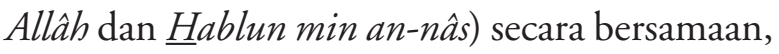
di luar kewenangan wilâyah qadhâ' dan wilâyah al-mazhâlim. ${ }^{55}$ Fuad, ${ }^{56}$ mencoba mengkonstruksi

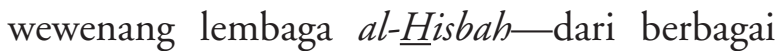
literatur Ekonomi Islam-ke dalam tiga bagian:

\footnotetext{
${ }^{53}$ Lihat Alâ’ ad-Dîn al-Muttaqî Ibn Hisâm ad-Dîn al-Hindî, Kanz al-Ummal fî Sunan al-Aqwâl wa al-Af'âl, h. 172.

54 Hasan Ibrâhim Hasan, Tarîkh al-Islâm: as-Siyâsi wa ad-Dîn̂̀ wa as-Saqafi wa al-Ijtihâdi, (Kairo: an-Nadwah alHashriyah, t.t.), 489. Lihat pula Abdul 'Azhim Ishlâhi, Muslim Economic Thinking and Institutions in the $10^{\text {th }}$ AH/1 $\sigma^{\text {th }}$ Century, (Jeddah: King Abdul Aziz University, 2009), 158. Lihat pila Abd al-'Azîz Sâlim, Tarîkh Daulah 'Arabiyah, (Iskandariyah: Muassasah Tsabab al-Jami'ah, 1997), h. 381.

55 Rambu-rambu pembatas kewenangan antara wilâyah alhisbah dengan wilâyah qadhâ' dan wilâyah al-mazhâlim antara lain adalah al-hisbah tidak boleh menyelesaikan perkara yang membutuhkan pembuktian dan sumpah. Lihat, al-Mawardi, alAhmâm ash-Shulthânitah..., h. 242-243.

${ }^{56}$ Fuad, "Pengawasan Pasar Dalam Islam (Studi Pemikiran Ibnu Taimiyah Tentang Hisbah”, Desertasi Doktor Pascasarjana UIN Sunan Kalijaga Yogyakarta, (Yogyakarta, 2016), h. 57-60.
} 
a. Perkara-perkara yang berkaitan dengan hakhak Allah.

(1) Al-Amru bi al-márûf, seperti salat lima waktu, puasa, membayar zakat, menunaikan ibadah haji, dan lain-lain.

(2) An-Nahyi 'an al-munkar. Dalam perkara aqidah, seperti: melarang/mencegah perbuatan-perbuatan yang dapat merusak aqidah (syirik). Dalam masalah ibadah, seperti melarang beribadah diluar tuntunan syari'at. Menyangkut larangan syara', seperti: mencegah perbuatanperbuatan yang dapat membawa kepada perbuatan keji, seperti laki-laki berada dalam suatu tempat dengan seseorang wanita yang bukan muhrim, dan lainlain. Sedangkan yang terkait dengan muamalah adalah transaksi yang tidak diperkenankan oleh syara', seperti penipuan, riba, mengurangi timbangan dan lain-lain.

b. Perkara-perkara yang berkaitan dengan hakhak manusia.

(1) Al-Amru bi al-márûf. Pertama, adalah halhal yang menyangkut keperluan manusia secara umum, seperti jaminan tersedianya air minum. Kedua, hak khusus, yang bersifat individual, seperti menyegerakan membayar hutang jika sudah ada kemampuan untuk membayarnya.

(2) An-Nahyi 'an al-munkar. Pertama, hak tetangga. Mu Htasib harus mencegah segala macam bentuk perbuatan zalim kepada tetangga. Kedua, profesionalitas dan kualitas pelayanan publik, seperti mencegah adanya malpraktik oleh para medis, kebiasaan penjahit tidak tepat janji dan sebagainya.

c. Perkara-perkara yang berkaitan dengan hakhak keduanya (Allah dan manusia)

(1) Al-Amru bi al-márûf. Antara lain adalah mengarahkan para orang tua untuk tidak menunda-nunda menikahkan anak perempuannya jika sudah meme- nuhi syarat; mewajibkan para wanita memenuhi masa iddah-nya; mengarahkan para kuli angkut yang menggunakan jasa hewan supaya tidak berlebihan dalam muatan, dan memberi makan yang cukup bagi hewannya.

(2) An-Nahyi an al-munkar. Antara lain mencegah para imam masjid memanjangkan bacaan dalam salat; mencegah pelanggaran privasi orang lain, seperti tindakan penyadapan tanpa hak, dan seterusnya.

\section{Tugas pokok al-Hisbah}

Berdasarkan pengertian dan kewenangan alHisbah di atas, maka dapat dikatakan bahwa tugas pokok lembaga al- $\underline{\text { Hisbahutamanya }}$ adalah melakukan pengawasan. Ada dua macam pengawasan yang menjadi tugas lembaga alHisbah:

a. Pengawasan yang bersifat umum, meliputi seluruh aspek kehidupan yang berkaitan dengan pelaksanaan kebajikan (al-amru bi al-márûf) dan mencegah kemungkaran (annahyi 'an al-munkar).

b. Pengawasan yang bersifat khusus, yaitu berkaitan dengan kegiatan pasar, seperti perindustrian dan perdagangan; berkaitan dengan administratif dan pemeliharaan kualitas dan standar produk.

(1) Melakukan pengecekan secara rutin terhadap ukuran, takaran dan timbangan.

(2) Menjaga kualitas barang.

(3) Menjaga kejujuran dan keadilan dalam setiap transaksi.

(4) Menjaga kesetabilan harga.

(5) Bila dianggap perlu, muhtasib dapat mengendalikan harga

Catatan penting yang menurut hemat penulis merupakan spesifikasi tugas pengawasan pada lemaga $\underline{H}$ isbah adalah pada aspek pencegahan. Hadis yang diriwayatkan Abi Hurairah pada kasus Rasulullah saw menegur keras penjual 
makanan seperti disebutkan di atas menjadi argumen kuat asumsi ini.

\section{Fungsi al-Hisbah}

Karena institusi al- Hisbah dibentuk oleh pemerintah dalam rangka mengemban tugas khusus untuk menjalankan 'amar ma'rûf dan nahyu 'an al-munkar, ${ }^{57}$ maka secara umum alHisbah berfungsi sebagai pelaksana apa yang menjadi misi pemerintah yang menugaskannya. Secara spesifik fungsi $\underline{H}$ isbah adalah fungsi pencegahan, fungsi pengendalian dan penindakan.

\section{Muhtasib}

Pada lembaga Hisbah, petugas yang bertanggung jawab melaksanakannya disebut mubtasib atau wali $\underline{H}$ isbah. Untuk mengemban amanah tersebut, oleh para fuqaha ditetapkan paling tidak ada empat kualifikasi, yaitu:

a. Merdeka. Bagi muhtasib, merdeka ini adalah persyaratan mutlak, tidak bisa ditawar-tawar. Merdeka tidak sekedar diartikan sebagai bukan budak, tapi lebih pada pribadi yang memiliki kemendirian berpikir, berkata dan bertindak dalam kapasitasnya sebagai hakim.

b. Adil. Islam menilai keadilan mencakup semua sendi kehidupan manusia. Harus tereaslisasikan dalam kehidupan individu, sosial, hukum, ekonomi, politik dan budaya. Bahkan penekanannya pada kehidupan pribadi, baik lahir maupun batin harus terbangun dan menjadi nyata, sampai pada berbangsa dan bernegara sekalipun. Dalam kerangka itulah, Allah memerintahkan untuk berlaku adil dan berbuat kebajikan, menyantuni kaum kerabat, melarang berbuat keji, kemungkaran dan permusuhan (Q.S. an-Nahl [16]: 90). Semua apa yang dilakukan manusia akan dipertanggung jawabkan, maka berbuat adil merupakan konsekuensi logis dari ajaran tauhid dalam Islam. ${ }^{58}$ Allah berfirman:

\footnotetext{
${ }^{57}$ Ibnu Taimiyah, al-Hisbah fì al-Islâm, h. 26.

${ }_{58}$ Amiur Nuruddin, Keadilan dalam al-Quran, (Jakarta: Hijri Pustaka Utama, 2008), h. 18.
}

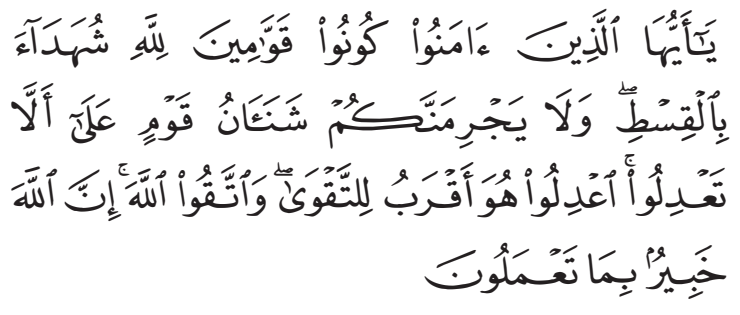

"Hai orang-orang yang beriman hendaklah kamu menjadi orang-orang yang selalu menegakkan (kebenaran) karena Allah, menjadi saksi dengan adil. Dan janganlah sekali-kali kebencianmu terhadap sesuatu kaum, mendorong kamu untuk berlaku tidak adil. Berlaku adillah, karena adil itu lebih dekat kepada takwa. Dan bertakwalah kepada Allah, sesungguhnya Allah Maha Mengetahui apa yang kamu kerjakan". (Q.S. AlMâidah [5]: 8)

c. Mempunyai pengetahuan tentang hal-hal yang secara jelas dipandang bertentangan dengan ukuran kepatutan. Karena persyaratan ini ditetapkan oleh Al-Mawardi

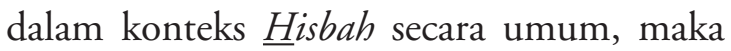
kualifikasi keilmuan atau pengetahuannya pun terlihat sangat umum. Dengan demikian maka yang dimaksudkan dengan hal-hal yang secara jelas dipandang bertentangan dengan ukuran kepatutan dalam persyaratan mubtasib adalah hal-hal yang bertentangan dengan kebijakan yang telah ditetapkan oleh pemerintah. Di samping itu pula bahwa kualifikasi ini mengisyaratkan mubtasib pada

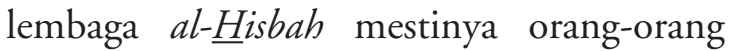
profesional di bidangnya. Islam menjunjung tinggi asas profesionalitas ini, sebagaimana sabda Rasulullah saw:

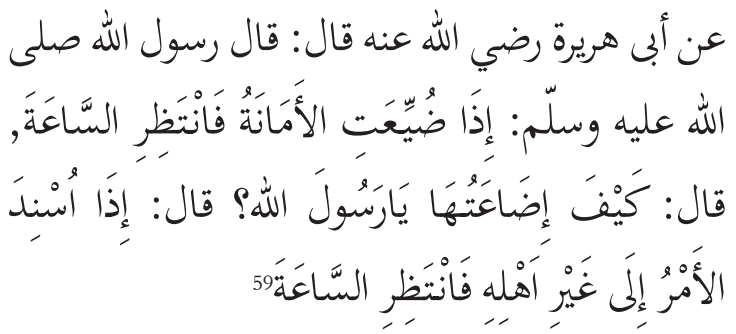

"Dari Abu Hurairah ra. ia berkata, Rasulullah SAW bersabda: Jika amanah telah hilang

${ }^{59}$ Al-Bukhârî, Abû 'Abdillâh Muhammad ibn Ismầ̂ll ibn Ibrâhim ibn al-Mugîrah al-Bukhârî, Shahîh al-Bukhârî, (Kitab ar-Riqaaq, bab Raf'ul Amaanah, XI, h. 333. 
(sudah tidak dipegang lagi dengan teguh), maka tunggulah saat kehancurannya. Ia bertanya: Ya Rasul, bagaimana orang menghilangkan amanah itu? Rasul menjawab: (yaitu) apabila suatu urusan (amanah) diserahkan kepada orang yang bukan ahlinya, maka tunggulah saat kehancurannya".

d. Bijaksana, tegas dan memiliki analisis yang tajam tentang pandangan keagamaan. ${ }^{60}$ Bijaksana artinya selalu menggunakan akal budinya (pengalaman dan pengetahuannya), arif, tajam pikiran; pandai dan hati-hati (cermat, teliti, dan sebagainya) apabila menghadapi kesulitan dan sebagainya. ${ }^{61}$ Bijaksana dapat diartikan sebagai berbuat sesuatu dengan carayang baik, banyak pertimbangan dengan akal yang sehat, arif dan santun dalam setiap keputusan. Sikap dan perilaku bijaksana akan mempengaruhi keputusan dan langkah-langkah dalam penyelesaian suatu persoalan. Orang yang bijak akan mampu mengendalikan emosi untuk mengambil keputusan, mandiri, teliti dan hati-hati, selalu berfikir positif dan menemukan hikmah dari segala peristiwa.

Dalam konteks al- $\underline{H i s b a h, ~ t u g a s ~ a l-a m r u ~ b i ~}$ al-márûf wa an-nahyu 'an al-munkar di samping misi penegakan hukum, ia juga membawa misi dakwah. Oleh karena itu seorang muhtasib dituntut bijaksana dalam melaksakan tugasnya, baik yang sifatnya mencegah, maupun menyuruh/perintah tidak boleh kaku, apa lagi berlaku kejam dan bertindak semena-mena. Bijaksana dalam sikap dan tindakan bagi seorang muhtasib sangat penting, sebab sekalipun pada waktunya ia harus menindak atau menghukum, maka hukuman itu apapun harus membawa efek pembelajaran.

Di samping bijaksana, sikap dan tindakan tegas juga dipersyaratkan bagi muhtasib. Tegas berarti jelas dan terang benar, tentu dan pasti

${ }^{60}$ Al-Mawardi, al-Ahkâm as-Sulthâniyyah, 241

${ }^{61}$ Departemen Pendidikan dan Kebudayaan RI, Kamus Besar Bahasa Indonesia, ed. II, cet. ke-2 (Jakarta: Balai Pustaka, 1995 ), h. 131. (tidak ragu dan tidak samar). Tegas dapat diartikan sebagai sikap yang berani dan percaya diri (tidak ragu) mengungkapkan dan melakukan apa yang diyakininya benar, mengungkapkan dan tidak melakukan apa yang menurut keyakinannya sebagai sesuatu yang tidak benar. Sikap dan tindakan tegas bagi muㅡtasib mutlak diperlukan, karena terkait dengan tugas dan tanggungjawab yang diembannya. Dalam menjalankan ugasnya sebagai pelaksana 'amr ma'rûf nahyi al-munkar, baik itu fungsinya sebagai pengawasan, maupun penindakan, tentu harus tegas menilai dan memutuskan perbuatan atau perilaku mana yang benar dan mana yang salah (melawan hukum).

Dalam hal muhtasib harus memiliki analisis yang tajam tentang pandangan keagamaan, adalah hal logis karena menyangkut kewenangan umum lembaga al- $\underline{H}$ isbah, yaitu meliputi seluruh pelanggaran terhadap prinsip-prinsip 'amr ma'rûf dan nahyi munkar yang berada di luar kewenangan wilâyah al-qadhâ' dan wilâyah al-mazhâlim, terutama hal-hal yang berkaitan dengan pelaksanaan ibadah.

\section{Penutup}

Setelah mencermati sistem dan tujuan ekonomi Islam dengan prinsip dan karakeristiknya, maka keberadaan lembaga al- $\underline{H}$ isbah dalam sistem ekonomi Islam adalah sebuah keniscayaan. Tanpa lembaga ini, makan sistem ekonomi Islam hanya sebatas konstruksi teori yang sulit untuk diimplementasikan dalam kehidupan nyata. Oleh sebab itu, tugas dan fungsi al- $\underline{H}$ isbah sudah dipraktikkan di dunia Islam, bahkan semenjak zaman Rasulullah saw, jauh sebelum dilembagakan. Dengan adanya lembaga pengawas pasar ini, maka segala bentuk tindakan penyimpangan dari pelaku pasar yang dapat merusak kemaslahatan dapat terdeteksi lebih dini, dan karenanya kemufsadatan dapat dihindari, atau paling tidak dapat diminimalisir. 


\section{Pustaka Acuan}

Abbas, Anwar, Philopsopy Sistem Ekonomi Islam, Jakarta, 14 Maret 2012.

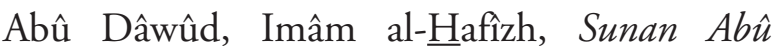
Dâwûd, juz 2, Beirut: Dâr al-Kutb alllmiyyah, t.th.

Afzalurrahman, Doktrin Ekonomi Islam, Yogyakarta: Dana Bhakti Wakf, 1996.

Agil, Syed Omar Syed, "Rationality in Economic Theory: A Critical Appraisal", dalam Sayyid Tahir et al. (ed.), Readings in Microeconomics An Islamic Perspective, Petaling Jaya: Longman Malaysia Sdn Bhd, 1992.

Akram, M. Khan, "Islamic Economics: Nature and Need", Journal of Research in Islamic Economics, Vol.1 (2), 1984

Al-Arif, M. Nur Rianto dan Euis Amalia, Teori Mikro Ekonomi: Suatu Perbandingan Ekonomi Islam Dan Ekonomi Konvensional, Jakarta: Kencana, 2010.

Bukhârî, Abû 'Abdillâh Muhammad ibn Ismâ'îl ibn Ibrâhim ibn al-Mugîrah al-, Shah $\underline{h} \underline{\underline{h}}$ al-Bukhârî, Kitab ar-Riqaaq, bab Raf'ul Amanah, Juz XI.

Gazali, Abu Hamid al-, Ihyâ U'lûddîn, jilid III, Beirut, Dâr an-Nadwah, t.th.

Al-Kaaf, Abdullah Zaky, Ekonomi dalam Perspektif Islam, Bandung: Penerbit Pusataka Setia Bandung, 2002, Cet. I.

Maududi, Abû al-A'lâ al-, Asas al-Iqtishad alIslâmî wa an-Nizhâm al-Ma'âsir Mu'dilat alIqtishad wa Halluha fî al-Islâm, Jeddah: Dâr as-Su'udiyah lî an-Nasr wa Tauzi, 1985.

Qardhawi, Yusuf al-, Daur al-Qiyâm wa alAkhlâq fi al-Iqtishâd al-Islâmî, Kairo: Maktabah Wahbah, 2001.

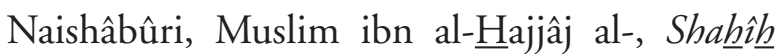
Muslim, Beirut: Dâr ihyâ at-Turâts al-'Arabî, t.th.

Rasul, Ali Abdurrahmân al-, Almadâdi' al-Iqtishâd fì al-Islàm, Kairo: Dâr al-Fikr al-Árabi, 1980.

Suyûthî, Jalâluddîn al-, Al-Ashbah wa anNazhâir, Semarang: Taha Putra, t.th.
Syarbasi, Ahmad al-, al-Mu'jâm al-Iqtishâdî alIslâmî, t.tp: Dâr al-Jîl, 1981.

Azid , Toseef, "Anthology of Islamic Economics: Review of Some Basic Issues", Journal Review of Islamic Economics, Vol. 13, No. 2, 2010.

Baltaji, Muhammad, Al-Milkiyah al-Fardiyah fì an-Nazhâm al-Iqtishadî al-Islâmî, Kairo, Dâr as-Salâm, 2007.

Chapra, M. Umer, What is Islamic Economics, Jeddah: Islamic Research and Training Institute Islami Devlopment Bank, 1996.

Fuad, "Pengawasan Pasar Dalam Islam (Studi Pemikiran Ibnu Taimiyah Tentang Hisbah", Desertasi Doktor Pascasarjana UIN Sunan Kalijaga Yogyakarta, Yogyakarta, 2016.

Hasan, Hasan Ibrâhim, Tarîkh al-Islâm: asSiyâsi wa ad-Dînî wa as-Saqafi wa al-Ijtihâdi, Kairo: an-Nadwah al-Hashriyah, t.th.

Taimiyyah, Ibn, Public Duties in Islam, The Institution of the Hisba, Translated from the Arabic by Muhtar Holland, London: The Islamic Foundation, 1982.

Imaniyati, Neni Sri, Perbankan Dsyariah dalam Perspektif Ilmu Ekonomi, Bandung: Bandar Maju, 2013.

Kahf, Monzer, The Islamic Economic Analitical of the Functioning of the Islamic Economic System, terj. Makhnum Husen, Ekonomi Islam: Tela’ah Analitik Terhadap Fungsi Sistem Ekonomi Islam, Yogyakarta: Pustaka Pelajar, 1995.

Kamal, Mustafa (ed.), Wawasan Islami dan Ekonomi: Sebuah Bunga Rampai, Jakarta, LPFEUI, 1997.

Karim, Adiwarman A. Ekonomi Mikro Islam, edisi kelima, cet. Ke-7, Jakarta: PT RajaGrafindo Persada, 2015.

Linda, Roza, Ekonomi Islami; Teori dan Aplikasinya Pada Aktivitas Ekonomi, Edisi ke-1, Cet. kedua, Jakarta, Rawali Pers, 2015.

Mannan, Muhammad Abdul., Islamic Economics: Theori and Practice (A Comperative Study), Delhi: Idarah Adabiyah, 1970.

Mardani, Hukum Sistem Ekonomi Islam, Jakarta: Rajawali Pers, 2015. 
Miller, Roger LeRoy, Economics Today: The Micro View, edisi 9, New York: Addison Wesley, 1997.

Munawir, A.W. Kamus al-Munawwir, Yogyakarta, t.th.

Rahardja, Pratama dan Mandala Manurung, Teori Ekonomi Mikro, Suatu Pengantar, Jakarta: Lembaga Penerbit Fakultas Ekonomi Universitas Indonesia, 2010.
Schiller, Bradley R., The Micro Economy Today, New York: McGraw-Hill, 2003.

Trianta, Agus, Hukum Ekonomi Islam: Dari Politik Hukum Ekonomi Islam Sampai Pranata Ekonomi Syariah, Yogyakarta: Fakultas Hukum UII Press, 2012.

Yusanto, M. Ismail, dan M. Arif Yunus, Pengantar Ekonomi Islam, Bogor: Al-Azhar Press, 2011, Cet. ke-2. 